\title{
Kualitas Semen Segar Sapi Bali Umur Produktif dan Non-produktif serta Penentuan Konsentrasi Krioprotektan dalam Pengencer Tris Kuning Telur
}

\author{
(FRESH SEMEN QUALITY OF BALI BULL IN PRODUCTIVE \\ AND NON-PRODUCTIVE AGES AND DETERMINATION \\ OF CRYOPROTECTANT CONCENTRATION IN TRIS EGGYOLK EXTENDER)
}

\author{
Anna Nabilla ${ }^{1,3}$, Raden Iis Arifiantini ${ }^{2}$, Bambang Purwantara ${ }^{2}$ \\ ${ }^{1}$ Program Studi Biologi Reproduksi, \\ Sekolah Pascasarjana, Institut Pertanian Bogor, \\ ${ }^{2}$ Divisi Reproduksi dan Kebidanan, \\ Departemen Klinik, Reproduksi, dan Patologi, \\ Fakultas Kedokteran Hewan, IPB, \\ Jl Agatis, Kampus IPB, Dramaga, Bogor, Jawa Barat, Indonesia, 16880. \\ ${ }^{3}$ Laboratorium Prossesing Semen Sapi Bali, \\ UPT Balai Inseminasi Buatan Daerah (BIBD) Baturiti. \\ Jalan Raya Bedugul Km 43, Baturiti, \\ PO. BOX 82191, Tabanan, Bali, Indonesia \\ Email: iis.arifiantinipurna@gmail.com; annanabilla@gmail.com
}

\begin{abstract}
ABSTRAK
Tujuan dari penelitian ini adalah membandingkan kualitas semen sapi bali pada kelompok umur produktif (di bawah 10 tahun) dengan kelompok umur lewat produktif (di atas 10 tahun) dan mengevaluasi kualitas semen beku sapi bali setelah kriopreservasi dalam pengencer Tris kuning telur menggunakan dimethylformamide (DMF) dan gliserol pada tiga konsentrasi (5\%, 6\%, dan 7\%). Semen dikoleksi menggunakan vagina buatan dan dievaluasi secara makro dan mikroskopis. Evaluasi makroskopis dilakukan secara visual dan mikroskopis menggunakan Computer Assisted Sperm Analysis (CASA). Setelah dievaluasi semen dibagi ke dalam enam tabung masing-masing diencerkan dengan Tris kuning telur (TKT) menggunakan gliserol 5\% (TKTG ${ }_{5}$ ), TKT-gliserol 6\% (TKTG ${ }_{6}$ ), TKT-gliserol 7\% (TKTG ${ }_{7}$ ), TKT-DMF 5\% $\left(\right.$ TKTD $\left._{5}\right)$, TKT-DMF 6\% (TKTD $)$ dan TKT-DMF 7\% (TKTD ${ }_{7}$ ). Hasil penelitian menunjukkan bahwa tidak ada perbedaan yang nyata $(\mathrm{P}>0,05)$ pada semua peubah kecuali volume semen. Volume semen kelompok produktif lebih tinggi daripada kelompok umur lewat produktif. Tidak terdapat perbedaan motilitas spermatozoa post thawing dalam pengencer TKT-Gliserol 5\% dengan TKT-DMF 5,6 dan 7\%. Nilai recovery rate spermatozoa paling tinggi ditunjukkan oleh spermatozoa dalam pengencer TKT dengan

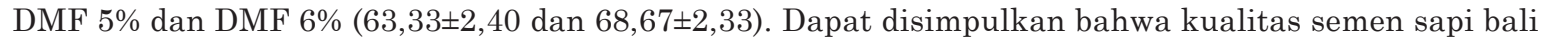
tidak berbeda antar kelompok produktif dengan kelompok umur lewat produktif dan kualitas semen post thawing dalam pengencer TKT 5-7\% DMF atau 5\% gliserol sama baiknya.
\end{abstract}

Kata-kata kunci: semen; sapi bali; DMF; gliserol; umur

\begin{abstract}
The aim of this study was to compare the quality of Bali bull fresh semen in productive group (below 10 years old) with over productive group and to evaluate the frozen semen quality of bali bull after cryopreservation in Tris egg yolk extender using Dimethyl formamide (DMF) and glycerol in three different concentrations $(5 \%, 6 \%$, and $7 \%)$. Semen was collected using artificial vagina. Semen then evaluated macro and microscopically. Macroscopic evaluation conducted visually and microscopic evaluation with the aid of Computer Assisted Sperm Analysis CASA. Immediatelly after evaluation, semen were divided into six aliquots and diluted with Tris egg yolk (TEY) glycerol 5\% (TEYG $\left.{ }_{5}\right)$, TEY-glycerol 6\% $\left(\mathrm{TEYG}_{6}\right)$, TEY
\end{abstract}


glycerol 7\% $\left(\mathrm{TEYG}_{7}\right)$, TEY-DMF 5\% (TKTD $)$, TEY-DMF 6\% (TEYD $)$ and TEY-DMF 7\% (TKTD $)$. Results of experiment showed that there was no difference $(\mathrm{P}>0.05)$ among the all parameters, except for semen volume. Semen volume of productive group was higher than over productive age group. No difference was found in post thawing motility of the spermatozoa in TEY extender with $5 \%$ glycerol, and TEY with $5 \%, 6 \%$ and $7 \%$ DMF. The higher recovery rate of bali bull spermatozoa demonstrated by spermatozoa in TEY extender with glycerol 5\% and DMF 6\% (63.33 \pm 2.40 dan 68.67 \pm 2.33$)$. It was concluded that bali bull semen quality did not differ between productive and over productive ages and post thawing semen quality of bali bull in TEY with 5-7\% DMF or 5\% glycerol was not also different.

Keywords : Bali bull; semen quality; DMF; glycerol

\section{PENDAHULUAN}

Sapi bali merupakan salah satu rumpun sapi yang penting dalam perkembangan industri peternakan di Indonesia dan sumber daya genetik sapi lokal yang memiliki potensi unggul. Sapi bali memiliki potensi genetik yang baik dan menguntungkan untuk dikembangkan karena konsumen memiliki minat yang baik terhadap presentase karkasnya yang tinggi (Purwantara et al. 2012). Perkembangbiakan sapi bali sebagian dilakukan dengan teknik inseminasi buatan (IB) menggunakan semen beku yang diproduksi di beberapa Balai Inseminasi Buatan (BIB).

Undang-Undang Nomor 41 Tahun 2014 yang merupakan perubahan atas UndangUndang nomor 18 Tahun 2009 tentang Peternakan dan Kesehatan Hewan diamanahkan dalam Pasal 13 ayat (6), bahwa setiap benih atau bibit yang beredar wajib memiliki sertifikat benih atau bibit yang memuat keterangan mengenai silsilah dan ciri-ciri keunggulannya. Oleh karena itu hasil produksi semen beku yang didistribusikan harus sesuai dengan SNI semen beku sapi. Sertifikasi produk benih dan bibit ternak dilakukan oleh lembaga sertifikasi produk (LsPro) benih dan bibit ternak, Kementrian Pertanian. Salah satu persyaratannya adalah, semen beku dihasilkan oleh pejantan yang mempunyai sertifikat dan umur produktif dengan umur maksimal 10 tahun.

Sapi bali merupakan sapi lokal yang kemungkinan mempunyai potensi reproduksi yang berbeda dibandingkan sapi-sapi eksotik seperti sapi simmental dan limousin. Potensi reproduksi termasuk umur produktif sapi bali perlu diteliti sehingga untuk sapi-sapi lokal umur produktif dalam menghasilkan semen beku dapat dibedakan dengan sapi eksotik, sehingga umur afkirnya di BIB juga berbeda. Potensi genetik yang unggul harus disertai teknis produksi semen beku yang baik. Proses pembekuan akan menurunkan kualitas semen hingga 50\% dari kondisi semen segar dan semen yang bertahan memiliki fertilitas rendah. Penggunaan pengencer yang tepat turut menentukan kualitas semen beku (Ariantie $e t$ al., 2013).

Penurunan kualitas semen terjadi pada saat produksi semen beku dan dapat diatasi dengan memanipulasi pengencer yang digunakan. Pengencer yang saat ini digunakan untuk sapi bali adalah pengencer komersial berbahan dasar soya lesitin dan Tris kuning telur (Arifiantini dan Purwantara, 2010). Tris kuning telur (TKT) memiliki kandungan yang relatif lengkap seperti Tris (hydroxymethylaminometan), asam sitrat, dan fruktosa. Fruktosa merupakan gugus gula sederhana dengan bobot molekul kecil seperti glukosa dan umum digunakan sebagai sumber karbohidrat sebagai penyedia energi untuk menjalankan fungsi fisiologi sel dalam proses kriopreservasi (Naing et al., 2010). Komponen-komponen dalam TKT dapat menjaga stabilitas $\mathrm{pH}$, mempertahankan tekanan osmotik, menjaga keseimbangan elektrolit, mengikat butir-butir lemak, sumber energi, serta melindungi sel spermatozoa dari cold shock (Herdiawan, 2004).

Spermatozoa juga membutuhkan krioprotektan, yakni bahan untuk mengurangi kerusakan sel pada saat pembekuan. Krioprotektan yang umum digunakan adalah gliserol. Berbagai jenis amida telah digunakan sebagai krioprotektan pada tahun 2000an, salah satunya dimethylformamide (DMF) pada ternak kuda (Osorio et al., 2008; Hoffman et al., 2011), pada ternak kambing (Moustacas et al., 2011; Ariantie et al., 2013). Krioprotektan DMF mempunyai bobot molekul yang lebih kecil daripada gliserol, sehingga daya penetrasinya lebih baik. Bobot molekul DMF adalah 73,09 g/ mol sedangkan gliserol adalah 92,09382 g/mol (Ball dan Vo, 2001). . Kriopropektan yang ideal harus memiliki bobot molekul yang rendah dengan dengan water solubility yang tinggi dan toksisitas yang rendah (Medeiros et al., 2002) 
Penelitian ini dilakukan bertujuan untuk membandingkan kualitas semen sapi umur produktif lewat umur produktif dan membandingkan kualitas semen beku sapi bali dalam pengencer Tris dengan berbagai konsentrasi gliserol dan DMF.

\section{METODE PENELITIAN}

Penelitian dilaksanakan pada bulan Februari-Maret 2017 di Laboratorium Prosessing Semen Sapi Bali, Unit Pelaksana Teknis (UPT), Balai Inseminasi Buatan Daerah (BIBD) Baturiti, Tabanan, Bali,.

\section{Sumber Semen}

Semen berasal dari sapi bali dengan kelompok pejantan umur produktif 4-9 tahun (di bawah 10 tahun) dan kelompok pejantan umur lewat produktif 10-14 tahun (di atas10) masing-masing terdiri dari tiga ekor. Sapi dipelihara dalam kandang individu yang dilengkapi dengan tempat pakan dan minum. Pakan diberikan $5 \mathrm{~kg} / \mathrm{ekor} / \mathrm{hari}$ dan hijauan 50 kg/ekor/hari. Pakan dan minum diberikan pada pagi dan sore hari, dan diimbuhi kecambah 1 $\mathrm{kg} / \mathrm{ekor} / \mathrm{minggu}$. Air minum diberikan secara ad libitum.

\section{Kualitas Semen Segar dan Beku}

Penelitian dibagi menjadi dua tahap. Tahap I, membandingkan kualitas semen segar sapi bali umur produktif dengan sapi bali yang lewat umur produktif. Tahap II menguji konsentrasi gliserol dan DMF terbaik dalam pengencer Tris kuning telur (TKT) untuk pembekuan semen sapi bali.

Tahap 1. Membandingkan kualitas semen segar sapi bali umur produktif dengan sapi bali yang lewat umur produktif. Tahap I menggunakan data sekunder BIBD Baturiti tahun 2016 dan data primer bulan Februari sampai Maret 2017. Data kualitas semen tahun 2016, ditabulasi, peubah yang diamati adalah kualitas makroskrokopis (volume, warna, konsistensi, dan $\mathrm{pH}$ semen) dan mikroskopis (gerakan massa, motilitas dan konsentrasi spermatozoa). Data ditabulasi, dicari rataan dan standard error means (SEM).

Koleksi semen. Semen dikoleksi menggunakan vagina buatan dari dua kelompok sapi umur produktif dan kelompok sapi umur lewat produktif dengan frekuensi penampungan dua kali/ekor/minggu dan dilakukan oleh bull master. Penampungan dilakukan jam 8.00-10.00 WITA.

Evaluasi Semen. Semen yang diperoleh dievaluasi secara makroskopis dan mikroskopis mengacu pada Baracaldo et al. (2007), Arifiantini dan Purwantara (2010), dan Arifiantini (2012). Evaluasi makroskopis yaitu volume semen $(\mathrm{mL})$, diamati dengan melihat skala yang tertera pada tabung penampung. Warna dilihat secara visual. Konsistensi diamati dengan cara memiringkan tabung penampung semen, kemudian ditegakkan kembali ke posisi semula, kriteria penilaian adalah kental, sedang, dan encer. Derajat keasaman $(\mathrm{pH})$ semen diukur menggunakan $\mathrm{pH}$ special indicator paper.

Evaluasi mikroskopis meliputi gerakan massa, dan skor gerakan individu, spermatozoa hidup dan mati (viabilitas) dan morfologi spermatozoa dengan pewarna eosin nigrosin menggunakan mikroskop (Olympus $\mathrm{CH} 21$ ) yang dilengkapi dengan heating table. Konsentrasi spermatozoa dihitung menggunakan photometer SDM 6. Evaluasi gerakan motilitas dilakukan menggunakan Computerized Assisted Sperm Analysis (Sperm vision, Minitub, Germany).

Tahap 2. Pengujian konsentrasi gliserol dan DMF terbaik dalam pengencer Tris-kuning telur (TKT) untuk pembekuan semen sapi bali.

Persiapan bahan pengencer. Tahap 2, menggunakan pengencer TKT yang terbuat dari $3.03 \mathrm{~g}$ Tris-hydroxymethyl-aminomethane, 1,78 g asam sitrat dan 1,25 g fruktosa, dilarutkan dalam $100 \mathrm{~mL}$ aquadest (Arifiantini dan Purwantara, 2010). Bahan pengencer semen beku terdiri atas enam macam yaitu TKT dengan tiga konsentrasi gliserol dan TKT dengan tiga konsentrasi DMF (Tabel 1).

Pengolahan Semen. Semen dikoleksi dan dievaluasi seperti pada Tahap I. Semen yang diproses menjadi semen beku adalah jika memiliki motilitas di atas $70 \%$ dengan konsentrasi spermatozoa di atas $1000 \mathrm{juta} / \mathrm{mL}$. Semen dibagi ke dalam enam tabung masingmasing diencerkan dengan $\mathrm{TKTG}_{5}, \mathrm{TKTG}_{6}$,

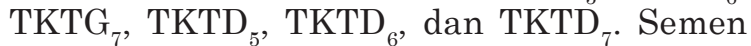
yang telah diencerkan dikemas dalam straw 0,25 $\mathrm{mL}$ kemudian diekuilibrasi selama 4 jam pada suhu $5^{\circ} \mathrm{C}$, setelah itu dibekukan di atas uap $\mathrm{N}_{2}$ cair sesuai prosedur di Balai Inseminasi Buatan Baturiti.

Evaluasi Semen Post thawing. Semen di thawing dalam penangas air atau waterbath (suhu $37^{\circ} \mathrm{C}$ ) kemudian dilakukan pengamatan terhadap motilitas spermatozoa (\%), viabilitas 
Tabel 1. Bahan pengencer semen beku sapi bali Tahap 2

\section{Pengencer semen}

Bahan

$\begin{array}{llllll}\text { TKTG }_{5} & \text { TKTG }_{6} & \text { TKTG }_{7} & \text { TKTD }_{5} & \text { TKTD }_{6} & \text { TKTD }_{7}\end{array}$

\begin{tabular}{lcccccc}
\hline Buffer Tris (\%) & 76 & 75 & 74 & 76 & 75 & 74 \\
Kuning telur (\%) & 20 & 20 & 20 & 20 & 20 & 20 \\
Gliserol (\%) & 5 & 6 & 7 & - & - & \\
DMF (\%) & - & - & - & 5 & 6 & 7 \\
Penisilin $\left(\mathrm{IU} \mathrm{mL} \mathrm{mL}^{-1}\right)$ & 1000 & 1000 & 1000 & 1000 & 1000 & 1000 \\
Streptomisin $\left(\mathrm{mg} \mathrm{ml}^{-1}\right)$ & 1 & 1 & 1 & 1 & 1 & 1 \\
\hline
\end{tabular}

Keterangan: $\mathrm{TKTG}_{5}=\mathrm{TKT}+$ gliserol $5 \% ; \mathrm{TKTG}_{6}=\mathrm{TKT}+$ gliserol $6 \% ; \mathrm{TKTG}_{7}=\mathrm{TKT}+$ gliserol $7 \% ; \mathrm{TKTD}_{5}=$ TKT+DMF $5 \% ;$ TKTD $_{6}=$ TKT+DMF $6 \% ;$ TKTD $_{7}=$ TKT + DMF $7 \%$;

spermatozoa (\%), membran plasma utuh spermatozoa (\%) dan menghitung recovery rate dengan rumus $\mathrm{RR}=$ (motilitas spermatozoa post thawing) $\mathrm{x}$ (motilitas spermatozoa segar $)^{-1} \mathrm{x}$ $100 \%$.

\section{Rancangan Penelitian dan Analisis Data}

Rancangan penelitian dan analisis data pada Tahap I menggunakan uji-t sampel berpasangan dan Tahap 2 menggunakan Rancangan Acak Lengkap (RAL) dengan dua jenis krioprotektan (gliserol dan DMF) masing-masing tiga konsentrasi, dilanjutkan dengan uji Duncan (Steel and Torrie 1993).

\section{HASIL DAN PEMBAHASAN}

\section{Kualitas Semen Segar Sapi Bali Umur} Produktif dan Lewat Produktif

Secara makroskopis semen segar sapi bali dari kedua kelompok umur produktif dan tidak produktif tidak menunjukkan perbedaan, kecuali untuk peubah volume. Volume semen kelompok umur produktif lebih tinggi $(\mathrm{P}<0.05)$ dibandingkan dengan volume semen kelompok umur lewat produktif (Tabel 3). Ada perbedaan warna semen sapi bali secara visual. Kelompok umur produktif berwarna putih susu sampai krem, namun pada umur lewat produktif putih susu. Secara mikroskopis, gerakan massa, skor individu, viabilitas, konsentrasi spermatozoa per $\mathrm{mL}$ dan konsentrasi spermatozoa per ejakulat serta morfologi spermatozoa menunjukkan nilai yang hampir sama, tidak terdapat perbedaan antar parameter yang diuji.

Hasil penelitian ini menunjukkan bahwa pejantan yang telah memasuki umur lewat produktif masih memiliki kemampuan dalam menghasilkan semen dengan kualitas yang sama dengan sapi umur produktif, namun dengan volume yang lebih rendah. Penurunan volume semen pada sapi lewat umur produktif diduga akibat jaringan organ reproduksi yang telah mengalami degenerasi. Vilakazi dan Webb (2004) menyatakan bahwa jaringan testikuler sapi $\mathrm{FH}$ berumur tua mengalami degenerasi yang memengaruhi kualitas dan kuantitas semen yang dihasilkan. Berbedanya volume semen tidak memengaruhi jumlah produksi semen beku, karena jumlah spermatozoa per ejakulat dari kedua kelompok umur tersebut sama. Volume semen sebenarnya juga dipengaruhi oleh teasing yang dilakukan oleh bull master. Teasing dilakukan dengan cara melakukan false mount beberapa kali. Secara fisiologis jantan pada saat teasing akan dirangsang melakukan emisi dan transportasi spermatozoa dari epididimis ke ampula duktus deferens (Senger, 2005) sehingga kualitas semen dan termasuk volume semen menjadi optimal.

Sapi umur produktif memiliki organ reproduksi yang telah berkembang sempurna sehingga semen yang dihasilkan memiliki kualitas dan kuantitas yang optimal (Balic et $a l ., 2012)$. Penelitian yang membandingkan kualitas semen dari umur produktif dan umur non produktif jarang dilakukan. Neto et al. (2013) melaporkan semen dari kuda tua memiliki kualitas yang sama dengan kuda muda dan dewasa. Hal ini menunjukkan bahwa pada kuda tua masih terjadi proses spermatogenesis dan fungsi termoregulasi yang masih baik. Kualitas semen yang dihasilkan dari kedua kelompok umur dalam penelitian ini termasuk normal, meskipun lebih rendah dari hasil penelitian Arifiantini et al. (2006) yang melaporkan rataan volume semen sapi bali 
sebesar $6,30 \pm 1,80 \mathrm{~mL}$ dengan konsentrasi $1.340 \pm 447,85$ juta spermatozoa per $\mathrm{mL}$.

Karakteristik motilitas pada kedua kelompok umur yang dievaluasi menggunakan CASA menunjukkan tidak berbeda $(\mathrm{P}>0,05)$. Motilitas total, motilitas progresif, immotile, linearity, straightness, wobble; beat cross frequency; amplitude of lateral displacement disajikan pada Tabel 4.

Menurut Katebi et al. (2005), LIN adalah indikator motilitas progresif yang berperan dalam karakteristik fungsi spermatozoa, STR adalah swimming pattern. WOB adalah goyangan spermatozoa terkuat per detik, sehingga berdasarkan hasil penelitian diketahui bahwa kelompok umur produktif memiliki kemampuan fertilisasi yang sama baiknya dibandingkan kelompok umur lewat produktif. Spermatozoa dinilai bergerak secara linear lurus ke depan jika menunjukkan nilai STR di atas 50 dan LIN di atas 35 (Minitube, 2004), maka dari hasil penelitian ini diketahui bahwa spermatozoa kedua kelompok umur bergerak secara linear.

Frekuensi gerakan spermatozoa per menit disebut $\mathrm{BCF}$ sehingga dapat diketahui bahwa frekuensi gerakan kelompok umur produktif tidak berbeda dibandingkan kelompok umur

Tabel 3. Karakteristik semen segar sapi bali (rerata \pm SEM)

\begin{tabular}{lcc}
\hline \multirow{2}{*}{ Peubah } & \multicolumn{2}{c}{ Kelompok umur } \\
\cline { 2 - 3 } & Umur produktif & Umur lewat produktif \\
\hline Makroskopis (n=123) & & \\
$\quad$ Volume (mL) & $6,44 \pm 0,23 \mathrm{a}$ & $5,44 \pm 0,12 \mathrm{~b}$ \\
$\quad$ Warna & Putih susu-krem & Putih susu \\
Konsistensi & Sedang & Sedang \\
pH & $6,4 \pm 1,37$ & $6,4 \pm 0,01$ \\
Mikroskopis & & \\
Gerakan massa (n=123) & $3,33 \pm 0,02$ & $3,30 \pm 0,03$ \\
Gerakan individu (n=9) & $2,89 \pm 0,16$ & $3,82 \pm 0,-25$ \\
Konsentrasi spermatozoa $\left(10^{6} \mathrm{sel}_{\mathrm{mL}}{ }^{-1}\right)$ & $1169,05 \pm 92,94$ & $1253,47 \pm 33,87$ \\
(n=123) & & \\
Viabilitas spermatozoa (\%) & $78,17 \pm 3,48$ & $72,67 \pm 4,28$ \\
$\quad$ Konsentrasi per ejakulat $\left(10^{6} \mathrm{sel}\right)$ & $7404,94 \pm 719,39$ & $6829,76 \pm 219,2$ \\
\hline
\end{tabular}

n 123 ( data sekunder dan data primer); n 9 (data primer)

Tabel 4. Karakteristik motilitas spermatozoa sapi bali menggunakan Computer Assisted Sperm Analysis (CASA)

\begin{tabular}{lcc}
\hline & \multicolumn{2}{c}{ Umur sapi } \\
\cline { 2 - 3 } Parameter & Produktif & Lewat produktif \\
\hline Total motility (\%) & $93,8 \pm 1,69$ & $91,69 \pm 2,13$ \\
Progressive Motility (\%) & $88,28 \pm 2,51$ & $83,06 \pm 3,11$ \\
Immotile (\%) & $6,41 \pm 1,58$ & $8,18 \pm 1,76$ \\
LIN (\%) & $50,00 \pm 0,03$ & $49,00 \pm 0,02$ \\
STR (\%) & $83,00 \pm 0,01$ & $81,00 \pm 0.009$ \\
WOB (\%) & $61,00 \pm 0,019$ & $60,00 \pm 0,018$ \\
BCF $($ beats/s) & $31,49 \pm 0,63$ & $29,90 \pm 1,51$ \\
ALH $(\mu \mathrm{m})$ & $6,54 \pm 0,21$ & $6,32 \pm 0,27$ \\
\hline
\end{tabular}

Keterangan: Immotile= Spermatozoa tidak bergerak; LIN = Linearity; STR= Straightness; WOB= Wobble; $\mathrm{BCF}=$ Beat cross frequency; ALH= Amplitude of lateral displacement of the sperm head. 
lewat produktif. Salah satu indikator gerakan hiperaktif dari spermatozoa adalah ALH. Nilai ALH di atas 7 ìm menandakan spermatozoa tersebut hiperaktif (Marquez dan Suarez, 2007). Gerakan spermatozoa sapi bali pada kedua kelompok umur tidak menunjukkan hiperaktif. Spermatozoa sapi bali hasil evaluasi menggunakan CASA pada penelitian ini menunjukkan karakteristik yang normal. Motilitas total dan motilitas progresif linier berkaitan erat dengan daya tahannya terhadap pembekuan dan tingkat fertilitas yang dilihat dari angka non-return rate (Kathiravan et al., 2010).

\section{Kualitas Semen Beku dalam TKT dengan Gliserol dan DMF}

Motilitas spermatozoa setelah ekuilibrasi dalam pengencer TKT dengan konsentrasi DMF $5 \%, 6 \%$, dan $7 \%$ menunjukkan, nilai yang hampir sama, ketiganya lebih tinggi dibandingkan spermatozoa dalam TKT dengan berbagai konsentrasi gliserol. Pada Tabel 5 disajikan kualitas spermatozoa setelah equilibrasi dan setelah thawing dalam pengencer TKT dengan berbagai konsentrasi gliserol dan DMF. Motilitas spermatozoa setelah thawing dalam pengencer TKT dengan berbagai konsentrasi DMF dan gliserol 5\% menunjukkan nilai yang sama, keempatnya lebih tinggi daripada TKTG $_{7}$.

Penggunaan DMF lebih mampu melindungi spermatozoa daripada gliserol pada saat proses pembekuan, kemungkinan disebabkan daya krioprotektif terhadap spermatozoa lebih tinggi. Pertimbangan pemilihan krioprotektan selain harus memiliki kemampuan melindungi spermatozoa pada saat pembekuan juga harus memiliki bobot molekul yang kecil agar mudah penetrasi ke dalam sel sehingga toksisitas akibat osmolaritas yang tinggi dapat diminimalisir.

Viabilitas spermatozoa dalam pengencer TKTD $_{5}$ TKTG $_{7}$ tidak berbeda $(\mathrm{P}>0,05)$ keduanya lebih tinggi daripada $\operatorname{TKTD}_{7}$. Tidak terdapat perbedaan viabilitas antara $\mathrm{TKTD}_{5}, \mathrm{TKTG}_{7}$, TKTD $_{6}$, TKTG $_{6}$, dan TKTG $_{5}$ demikian juga antara TKTD $_{5}$, TKTD $_{7}$, TKTD $_{6}$ TKTG $_{6}$, dan TKTG $_{5}$ Keutuhan membran plasma spermatozoa tidak berbeda pada seluruh konsentrasi gliserol ataupun DMF dengan nilai antara $77,72 \%$ sampai dengan $82,16 \%$.

Motilitas setelah thawing secara keseluruhan lebih rendah dibandingkan motilitas spermatozoa setelah ekuilibrasi. Hal ini disebabkan proses pembekuan menyebabkan spermatozoa kehilangan kemampuan untuk bergerak akibat rusaknya membran sel. Membran plasma yang masih utuh memberikan korelasi positif terhadap motilitas dan viabilitas karena transpor ion tetap berlangsung dan proses metabolisme sel dapat berjalan dengan baik. Kerusakan membran plasma dapat terjadi pada bagian kepala dan bagian ekor. Kerusakan bagian kepala menyebabkan penurunan viabilitas, kerusakan bagian ekor terutama pada bagian midpiece akan berakibat hilangnya kemampuan mitokondria menghasilkan ATP terhambat sehingga energi untuk pergerakan tidak terbentuk dan spermatozoa berhenti bergerak (Arifiantini dan Yusuf, 2010).

Pada tahap kriopreservasi yaitu pengenceran, pendinginan dan pembekuan terjadi perubahan tekanan osmotik dan

Tabel 5. Kualitas semen sapi bali setelah dibekukan dalam pengencer TKT dengan berbagai konsentrasi gliserol dan DMF

\begin{tabular}{|c|c|c|c|c|c|c|}
\hline \multirow{2}{*}{ Parameter } & \multicolumn{6}{|c|}{ Pengencer } \\
\hline & TKTG $_{5}$ & $\mathrm{TKTG}_{6}$ & TKTG $_{7}$ & TKTD $_{5}$ & TKTD $_{6}$ & TKTD $_{7}$ \\
\hline \multicolumn{7}{|l|}{ SS } \\
\hline SE & & & & & & \\
\hline ST ${ }_{\text {Sotilitas (\%) }}$ & $65,33 \pm 1,97 \mathrm{ab}$ & $67,00 \pm 1,01 \mathrm{bc}$ & $63,83 \pm 1,00 \mathrm{a}$ & $70,16 \pm 0,9 \mathrm{~d}$ & $69,00 \pm 0,30 \mathrm{~cd}$ & $68,80 \pm 0,30 \mathrm{~cd}$ \\
\hline Motilitas (\%) & $50,22 \pm 2,60 \mathrm{~b}$ & $44,05 \pm 2,47 \mathrm{ab}$ & $40,72 \pm 2,20 \mathrm{a}$ & $50,44 \pm 1,90 \mathrm{~b}$ & $47,83 \pm 1,30 \mathrm{~b}$ & $48,00 \pm 2,17 \mathrm{~b}$ \\
\hline Viabilitas (\%) & $57,11 \pm 2,74 \mathrm{ab}$ & $57,05 \pm 2,16 \mathrm{ab}$ & $58,89 \pm 2,81 \mathrm{~b}$ & $59,5 \pm 2,00 \mathrm{~b}$ & $58,83 \pm 2,40 \mathrm{ab}$ & $51,16 \pm 2,20 \mathrm{a}$ \\
\hline MPU (\%) & $82,16 \pm 3,76$ & $79,11 \pm 4,54$ & $77,72 \pm 5,37$ & $81,16 \pm 4,13$ & $77,77 \pm 5,01$ & $80,33 \pm 4,48$ \\
\hline
\end{tabular}

Keterangan: Huruf berbeda yang mengikuti angka pada baris yang sama menunjukkan berbeda nyata $(\mathrm{P}<0,05) . \mathrm{SS}=$ Semen segar, $\mathrm{SE}=$ Setelah equilibrasi, $\mathrm{ST}=$ Setelah thawing, $\mathrm{MPU}=$ membran plasma utuh 


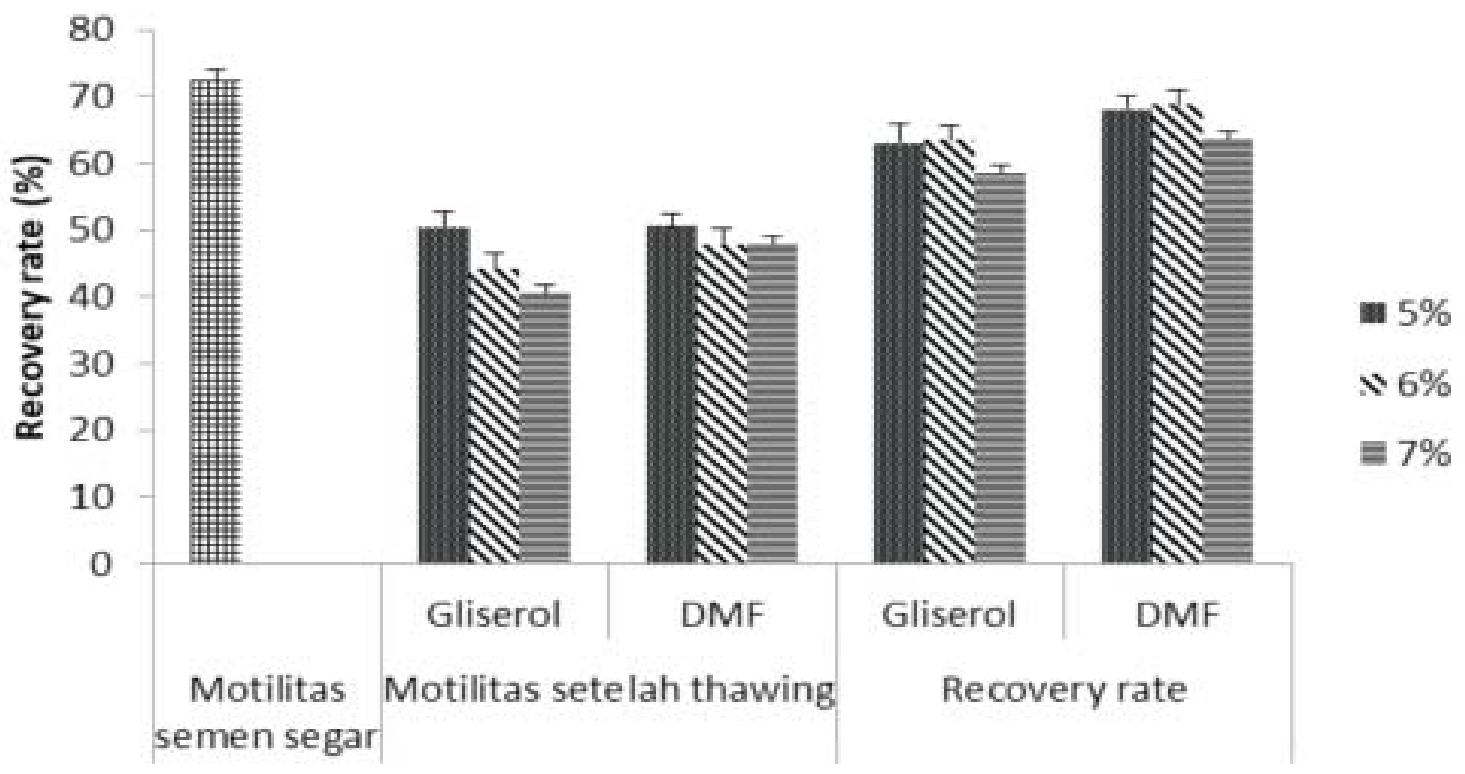

Gambar 1. Recovery rate spermatozoa dalam pengencer TKT dengan berbagai konsentrasi krioprotektan gliserol dan DMF

perubahan suhu yang ekstrim. Perubahanperubahan tersebut berpotensi merusak membran plasma dan akrosom spermatozoa yang pada akhirnya akan berpengaruh pada penurunan viabilitas spermatozoa (Bag et al., 2002). Hasil penelitian menunjukkan secara keseluruhan penggunaan gliserol dan DMF dalam pengencer TKT mampu menjaga motilitas spermatozoa sapi bali setelah thawing. Pada Tabel 5 disajikan nilai motilitas spermatozoa lebih dari 40\% (Batas minimal SNI semen beku sapi), sehingga semen beku dalam pengencer dan krioprotektan ini layak untuk digunakan IB. Pengencer TKT berbahan dasar buffer Tris (hydroxymethyl) aminomethane memiliki kemampuan melindungi spermatozoa pada saat pembekuan dengan menjaga keseimbangan intraseluler dan ekstraseluler sehingga proses metabolisme sel tetap berlangsung dan kematian sel berkurang.

Penggunaan DMF pada pembekuan berbagai semen telah dilaporkan. Pada semen babi menggunakan pengencer Beltsville thawing solution (BTS) konsentrasi DMF terbaik adalah 5\% (Bianchi et al., 2008). Konsentrasi terbaik pada semen kuda adalah 2,5\% (Pukazhenthi et al., 2014). Konsentrasi terbaik pada semen domba dalam pengencer skim soya adalah $6 \%$ (Jerez et al., 2016). Penggunaan DMF untuk pembekuan semen anjing menurut Lopes et al. (2009) tidak lebih baik dibandingkan gliserol. Pembekuan semen sapi menggunakan DMF masih jarang dilakukan. Oh et al. (2012) melaporkan pembekuan semen sapi Korean Jeju Black dalam pengencer Tris kuning telur yang diberi DMF 5\% sama baiknya dengan yang diberi gliserol 7\%.

Salah satu parameter keberhasilan kriopreservasi pada semen adalah nilai Recovery rate (RR). Recovery rate merupakan kemampuan spermatozoa pulih dari pembekuan. Nilai RR dari spermatozoa dalam pengencer TKT dengan berbagai konsentrasi krioprotektan disajikan pada Gambar 1. Nilai RR tertinggi ditunjukkan oleh spematozoa dalam pengencer TKT dengan gliserol dan DMF 6\% (63,33 $\pm 2,40$ dan $68,67 \pm 2,33)$. Recovery rate dapat digunakan sebagai indikator kemampuan pengencer dan krioprotektan yang mampu menjaga sel spermatozoa selama proses kriopreservasi. Nilai RR pada spermatozoa sapi pasundan dalam pengencer Tris adalah 59,62 $\pm 5,57$ (Baharun et al., 2017). Spermatozoa sapi limousin, simmental dan $\mathrm{FH}$ dalam pengencer skim kuning telur mempunyai nilai RR berturutturut adalah $58,87 \pm 6,37 ; 56,27 \pm 7,08 ; 58,87 \pm 5,31$ (Komariah et al., 2013).

Berdasarkan hasil penelitian, semen sapi bali dari pejantan yang berumur di atas 10 tahun, masih menunjukkan kualitas semen yang baik, sehingga dapat diusulkan untuk memperpanjang masa penggunaan pejantan sapi bali sebagai sumber semen beku agar dapat dibedakan dengan sapi bangsa lain. 
Krioprotektan gliserol 5\% dan DMF 5\%, 6\%, dan $7 \%$ dalam pengencer TKT sama-sama menghasilkan semen beku dengan kualitas yang baik.

\section{SIMPULAN}

Kualitas semen segar sapi bali pada kelompok umur produktif dan umur lewat produktif tidak berbeda kecuali, pada volume semen. Kualitas semen beku sapi bali dalam pengencer TKT pada konsentrasi gliserol 5\%, DMF 5\%, 6\%, dan 7\% menunjukkan hasil yang sama, lebih baik dari gliserol 6 dan $7 \%$.

\section{SARAN}

Perlu dipertimbangan dalam peraturan afkir sapi bali lebih panjang dari sapi eksotik. Alternatif penggunaan DMF sebagai pengganti krioprotektan gliseroldi BIB perlu dipertimbangkan.

\section{UCAPAN TERIMA KASIH}

Terima kasih kami ucapkan kepada Kepala Dinas Peternakan dan Kesehatan Hewan, Provinsi Bali dan Kepala Balai Inseminasi Buatan Daerah Baturiti beserta seluruh stafatas izin penelitian dan fasilitas yang diberikan selama penelitian dilaksanakan.

\section{DAFTAR PUSTAKA}

Ariantie OS, Yusuf TL, Sajuti D, Arifiantini RI. 2013. Pengaruh Krioprotektan Gliserol dan Dimetilformamida dalam Pembekuan Semen Kambing Peranakan Etawah Menggunakan Pengencer Tris Modifikasi. Jurnal Ilmu Ternak dan Veteriner 18: 239250.

Arifiantini RI. 2012. Teknik Koleksi dan Evaluasi Semen pada Hewan. Bogor (ID): IPB Press.

Arifiantini RI, Purwantara B. 2010. Motility and Viability of Frisian Holstein Spermatozoa in Three Different Extender Stored at $5^{\circ} \mathrm{C}$. Indones Trop Anim Agric 35(4): 222-226.
Arifiantini RI, Wresdiyati T, Retnani E F. 2006. Pengujian Morfologi Spermatozoa Sapi Bali (Bos sondaicus) Menggunakan Pewarnaan "Williams". J Indones Trop Anim Agric 31(2): 105-110.

Arifiantini RI, Yusuf TL. 2010. Developing of Tris Soy Milk Diluent for Frisian Holstein bull frozen semen. Hayati J of Biol 17(2): 91-94

Bag S, Joshi A, Naqvi SMK, Rawat PS, Mittal JP. 2002. Effect of Freezing Temperature. at Which Straw Were Plunged into Liquid Nitrogen. on The Post-Thaw Motility and Acrosomal Status of Ram Spermatozoa. Anim Reprod Sci 72: 175-183.

Baharun A, Arifiantini RI, Yusuf TL. 2017. Freezing capability of pasundan bull sperm using Tris egg yolk, Tris-soy, and Andromed $₫$ diluents. J Ked Hewan. 11(1): 4549.

Balic IM, Milinkovic-Tur S, Samardzija M, Vince S. 2012. Effect of age and environmental factors on semen quality, glutathione peroxidase activity and oxidative parameters in simmental bulls. Theriogenology 78(2): 423431.

Bianchi I, Calderam K, Maschio EF, Madeira EM, Ulguim RR, Corcini CD, Bongalhardo DC, Correa EK, Lucia T Jr, Deschamps JC, Correa MN. 2008. Evaluation of amides and centrifugation temperature in boar semen cryopreservation. Theriogenology 69(5): 632-638.

Ball BA, Vo A. 2001. Osmotic tolerance of equine spermatozoa and the effects of soluble cryoprotectants on equine sperm motility, viability and mitochondrial membrane potential. JAndrol 22(6): 1061-1069.

Baracaldo MI, Barth AD, Bertrand W. 2007. Steps for Freezing Bovine Semen: from Semen Collection to the Liquid Nitrogen Tank. IVIS Reviews in Veterinary Medicine. I.V.I.S. (Ed.). International Veterinary Information Service. Ithaca NY.

Herdiawan I. 2004. Pengaruh Laju Penurunan Suhu dan Jenis Pengencer terhadap Kualitas Semen Beku Domba Priangan. Jurnal Ilmu Ternak dan Veteriner 9(2): 98 107. 
Hoffman N, Oldenhof H, Morandini C, Rohn K, Sieme H. 2011. Optimal Concentrations of Cryoprotective Agents for Semen from Stallions that are Classified 'Good' or 'Poor' for Freezing. Anim Reprod Sci 125: 112 118.

Oh SA, Choi SH, Ko MH, Kang TY, Cho SR, Ko MS, Oh YM, Cho WM. 2012. Effect of amides as a cryoprotectant on quality of frozenthawed sperm in Korean Jeju Black bull. $J$ Anim Sci Tech-54:_95-101.

Jerez R, Gonzales N, Olaciregui M, Luno V, Blas I, Gil L. 2015. Use of soy milk combined with different cryoprotectans for the ram semen cryopreservation. Small Rum Res 134: $34-38$

Katebi M, Movahedin M, Abdolvahabi AM, Akabar M, Abohassani F, Sobhani A, Aoki F. 2005. Changes in Motility Parameters of Mouse Spermatozoa in Response to Different Doses of Progesteron during Course of Hyperactivation. Iranian Biomed J 9(2): 73-79

Kathiravan P, Kalatharan J, Karthikeya G, Rengarajan K, Kadirvel G. 2011. Objective sperm motion analysis to assess dairy bull fertility using computer-aided system - a review. Reprod Dom Anim 46: 165-172.

Komariah, Arifiantini RI, Nugraha FW. 2013. Kaji banding kualitas spermatozoa sapi simmental, limousin, dan friesian holstein terhadap proses pembekuan. Buletin Peternakan 37(3): 143-147

Lopes KRF, Costa LLM, Lima GL, Souza ALP, Silva AR. 2009. Dimethylformamide is no better than glycerol for cryopreservation of canine semen. Theriogenology 72: 650-654

Marquez B, Suarez SS. 2007. Bovine sperm hyperactivation is promoted by alkalinestimulated $\mathrm{Ca}^{2+}$ influx. Biol Reprod 76: 660665.

Minitube. Instructions Sperm Vision ${ }^{\mathrm{TM}} .2004$. Art. No.12049/Minitube. Tiefenbach. Germany.

Medeiros ASL, Gomes GM, Carmo MT, Papa FO, Alverenga, MA. 2002. Cryopreservation of stallion sperm using different amides. Theriogenology 58: 273-276.

Moustacas VS, Cruz BC, Varago FC, Miranda DA, Lage PG, Henry M. 2011. Extenders
Containing Dimethylformamide Associated or Not with Glycerol are Ineffective for Ovine Sperm Cryopreservation. Reprod Dom Anim 46(5): 924-925.

Naing SW, Wahid H, Azam KM, Rosnina Y, Zuki AB, Kazhala S, Bukara MM, Thein M, Kyaw T, San MM. 2010. Effect of Sugars on Characteristics of Boer Goat Semen After Cryopreservation. Anim Reprod Sci 122(12): $23-28$.

Neto CR, Monteiro GA, Delfiol DJZ, Farras MC, Dell'aqua Jr JA, Papa FO, Alvarenga MA. 2013. The relationships between scrotal surface temperature, age and sperm quality in stallions. Liv Sci 157(1): 358-363.

Osorio JP, Mello FGC, Juliani GC, Lagares MA, Lago LA, Henry M. 2008. Effect on PostThaw Viability of Equine Sperm Using Stepwise Addition of Dimethylformamide and Varying Cooling and Freezing Procedures. Anim Reprod Sci 5(3/4): 103109.

Pukazhenthi BS, Johnson A, Guthrie HD, Songsasen N, Padilla LR, Wolfe BA, Silva MC, Alvarenga MA, Wildt DE. 2014. Improved sperm cryosurvival in diluents containing amides versus glycerol in the Przewalski's horse (Equus ferus przewalskii). Cryobiology 68(2): 205-214.

Purwantara B, Noor RR, Andersson G, Rodriguez-Martinez H. 2012. Banteng and Bali Cattle in Indonesia: Status and Forecasts. Reprod Dom Anim 47(Suppl. 1): 2-6.

Senger PL. 2005. Pathways to Pregnancy and Parturation. Current Concepton. Washington. Washington State University Research and Technology Park.

Steel RGD, Torrie JH. 1993. Prinsip dan prosedur statistika. Jakarta (ID). Gramedia Pustaka Utama.

Undang-Undang No. 41 tahun 2014. Tentang Perubahan Atas Undang-Undang Nomor 18 Tahun 2009 Tentang Peternakan dan Kesehatan Hewan.

Vilakazi DM, Webb EC. 2004. Effect of age and season on sperm morphology of Friesland bulls at an artificial insemination centre in South Africa. South Africa J Anim Sci 34: 62-69. 